\title{
PENGARUH KEDISIPLINAN KERJA DAN KESEHATAN KERJA TERHADAP PRODUKTIVITAS KERJA KARYAWAN PADA PT. SEMEN TONASA GEROKGAK JALAN PELABUHAN CELUKAN BAWANG, BALI.
}

\author{
Kadek Dwi Nitayani ${ }^{1}$, Lulup Endah Tripalupi ${ }^{2}$, Iyus Akhmad Haris ${ }^{3}$ \\ Jurusan Pendidikan Ekonomi \\ Universitas Pendidikan Ganesha \\ Singaraja, Indonesia
}

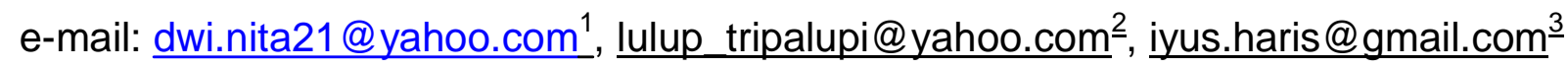

\begin{abstract}
Abstrak
Penelitian ini bertujuan untuk mengetahui pengaruh kedisiplinan kerja dan kesehatan kerja secara parsial dan simultan terhadap produktivitas kerja karyawan pada PT. Semen Tonasa Gerokgak. Penelitian ini merupakan penelitian kausalitas dengan sampel dalam penelitian ini adalah 66 karyawan. Data dikumpulkan menggunakan metode kuesioner dan dianalisis dengan uji $t$-test, uji $f$-test, dengan program SPSS versi 16.0 for windows. Hasil penelitian menunjukkan bahwa ada pengaruh signifikan antara kedisiplinan kerja dan kesehatan kerja secara parsial terhadap produktivitas kerja karyawan ditunjukkan dengan nilai t-test $=4,939$ untuk kedisiplinan kerja, nilai t-test $=$ 6,226 untuk kesehatan kerja dan secara simultan ditunjukkan dengan nilai f-test $=$ $96,737>\mathrm{f}$-tabel $=3,15$ atau $\mathrm{p}$-value $0,000<\alpha=0,05$.
\end{abstract}

Kata kunci: kedisiplinan, kesehatan kerja, produktivitas

\begin{abstract}
This study aimed to know the effect of work discipline and work health partial and simultan on employees productivity at PT. Semen Tonasa Gerokgak. This study used causality research with sample in this research was 66 employees. The data were collected through questionnaire method and analyzed by t-test, f-test with SPSS version 16.0 for windows. The results of study showed that there was significant influence between work discipline and work health partial and simultan to work productivity of employees that was shown value of t-test $=4,939$ for work discipline, value of t-test $=6,226$ for work health and simultan that was shown by value f-test $=$ $96,737>$ f-table $=3,15$ or $p$-value $0,000<\alpha=0.05$.
\end{abstract}

Keywords: dicipline, work health, productivity

\section{PENDAHULUAN}

Produktivitas kerja karyawan merupakan faktor utama bagi suatu perusahaan dalam mencapai tujuan yang diinginkan. Menurut Sunyoto (2012:41) "produktivitas merupakan sikap mental yang selalu berusaha dan mempunyai pandangan bahwa suatu kehidupan hari ini lebih baik dari hari kemarin dan hari esok lebih baik dari hari ini". Menurut Ervianto (2004) produktivitas didefinisikan sebagai rasio antara output dan input, atau rasio antara hasil produk dengan total sumber daya yang digunakan. Konsep produktivitas erat hubungannya dengan efisiensi dan efektivitas (Gomes, 2000). Efektivitas dan efisiensi yang tinggi akan menghasilkan produktivitas yang tinggi. Dan jika efektivitas dan efisiensi rendah, maka diasumsikan telah terjadi kesalahan manajemen. Jika efektivitas tinggi tetapi efisiensi rendah dimungkinkan terjadi pemborosan (biaya tinggi), sementara bila efisiensi tinggi namun efektivitas rendah, berati tidak tercapai sasaran atau terjadinya penyimpangan dari target. Faktor yang 
mempengaruhi produktivitas kerja karyawan yaitu pendidikan, keterampilan, disiplin, sikap mental dan etika kerja, motivasi, gizi dan kesehatan, tingkat penghasilan, jaminan sosial, lingkungan dan iklim kerja, hubungan industrial Pancasila, teknologi, sarana produksi, manajemen, kesempatan berprestasi. Ada beberapa faktor yang berpengaruh pada peningkatan produktivitas kerja karyawan, antara lain kedisiplinan dan kesehatan. Dengan memperhatikan kedisiplinan dan kesehatan kerja diharapkan dapat meningkatkan produktivitas kerja karyawan dalam melaksanakan pekerjaannya. Faktor produksi di perusahaan dapat di lihat dari pengukuran kontribusinya terhadap output dari suatu proses produksi sering dihadapkan pada berbagai kesulitan. Kedudukan manusia, baik sebagai pekerja maupun sebagai manajer di perusahaan tentunya juga sangat diperlukan dalam proses produksi. Mengingat pentingnya manusia dalam suatu perusahaan, yang apabila salah memanfaatkan tenaga kerja manusia akan dapat menimbulkan masalah yang sangat rumit, yang justru bisa menghancurkan tujuan perusahaan. Untuk itu, tenaga kerja manusia sangat perlu mendapatkan perhatian yang khusus karena pemakaian tenaga kerja manusia secara efektif merupakan kunci dari peningkatan produktivitas.

Kedisiplinan sangat mempengaruhi produktivitas kerja karyawan di perusahaan. Singodimedjo (2002) mengatakan disiplin adalah sikap kesediaan dan kerelaan seseorang untuk mematuhi dan menaati norma-norma peraturan yang berlaku disekitarnya. "Kedisiplinan merupakan fungsi operatif Manajemen Sumber Daya Manusia (MSDM) yang terpenting karena semakin baik disiplin karyawan, semakin tinggi tingkat produktivitas yang akan dicapai" (Hasibuan, 2012:193). Tanpa disiplin karyawan yang baik, sulit bagi perusahaan mencapai hasil yang optimal. Menurut Sutrisno (2009) kedisiplinan kerja adalah sikap, tingkah laku, dan perbuatan yang sesuai dengan peraturan dari organisasi baik tertulis maupun yang tidak tertulis dengan mematuhi semua aturan dan norma yang ada dalam menjalankan tugasnya sebagai bentuk tanggung jawabnya terhadap pekerjaannya. Menurut Buhler (2007:216-218) "disiplin kerja karyawan yaitu benar-benar memainkan peran penting dalam membentuk tingkah laku karyawan". Kedisiplinan memiliki peran penting dalam membentuk tingkah laku di suatu perusahaan. Seperti halnya penghargaan yang efektif dalam memotivasi orang, disiplin jika digunakan secara tepat maka dapat sama-sama efektif. Disiplin kerja pada karyawan sangat dibutuhkan, karena apa yang menjadi tujuan perusahaan akan sukar dicapai bila tidak ada disiplin kerja. Kecelakaan kerja bisa terjadi apabila pegawai dan karyawan tidak mematuhi peraturan kedisiplinan yang berlaku di perusahaan. Kedisiplinan kerja karyawan mendorong gairah atau semangat kerja karyawan, sehingga perlu ditingkatkan dalam setiap organisasi baik organisasi pemerintah maupun swasta, karena tanpa dukungan kedisiplinan karyawan yang baik maka organisasi akan mengalami kesulitan dalam mewujudkan tujuan perusahaan.

Seperti yang telah dijelaskan di atas yang mempengaruhi produktivitas kedisiplinan adalah kesehatan kerja. Menurut Mangkunegara (2000:161) "program kesehatan kerja menunjukkan pada kondisi yang bebas dari gangguan fisik, mental, emosi atau rasa sakit yang disebabkan oleh lingkungan". Resiko kesehatan merupakan faktor-faktor dalam lingkungan kerja yang bekerja melebihi periode waktu yang ditentukan. Menurut Mathis dan Jackson (2002:45) menyatakan bahwa "kesehatan adalah merujuk pada kondisi umum fisik, mental dan stabilitas emosi secara umum". Notoatmodjo (2002) menyatakan bahwa kesehatan kerja merupakan aplikasi kesehatan masyarakat di dalam suatu tempat kerja (perusahaan, pabrik, kantor, dan sebagainya) dan yang menjadi pasien dari kesehatan kerja ialah para pekerja dan masyarakat sekitar perusahan tersebut. Ciri pokoknya adalah preventif (pencegahan penyakit) dan promotif (peningkatan kesehatan. Dari aspek ekonomi, penyelenggaraan kesehatan kerja bagi suatu perusahaan adalah sangat menguntungkan karena tujuan akhir dari kesehatan kerja ialah meningkatkan produktivitas seoptimal 
mungkin. Apabila kesehatan kerja karyawan menurun otomatis produktivitas kerja karyawan di perusahaan akan ikut menurun karena gangguan kesehatan karyawan yang membuat para pekerja atau karyawan tidak bersemangat. Gangguan kesehatan ini disebabkan karena karyawan yang tidak menggunakan peralatan lengkap atau Alat Pelindung Diri (APD). Contohnya polusi udara masuk ke dalam tubuh akibat tidak menggunakan masker khusus sehingga kondisi karyawan melemah. Kesehatan karyawan akan berpengaruh pada kondisi karyawan, konsumen, masyarakat dan lingkungan sekitar perusahaan. Agar karyawan dapat terjamin kesehatan dan produktivitas kerja setinggitingginya maka perlu keseimbangan yang menguntungkan dari faktor beban kerja, beban tambahan akibat lingkungan kerja dan kapasitas kerja.

Salah satunya adalah perusahaan PT. Semen Tonasa yang terletak di Kecamatan Gerokgak, Kabupaten Buleleng Jalan Pelabuhan Celukan Bawang, Bali. Perusahaan ini bergerak dalam bidang unit pengantongan semen. Selain penjualan dalam negeri penjualan ekspor juga dilakukan perusahaan jika terjadi kelebihan produksi setelah pemenuhan pasar dalam negeri. PT. Semen tonasa disini memiliki delapan cabang unit pengantongan semen. Dimana ada di Sulawesi Utara, Sulawesi Selatan, Sulawesi Tengah, Maluku, Bali, Papua, Kalimantan Timur, dan Kalimantan Selatan. Proses kerja dilakukan diluar ruangan yang dekat pula dengan pantai. Proses produksi perseroan bermula dari kegiatan penambangan tanah liat dan batu kapur di kawasan tambang tanah liat dan pegunungan batu kapur sekitar pabrik hingga pengantongan semen zak di unit pengantongan semen. Proses produksi perseroan secara terus menerus dipantau oleh satuan Quality Control guna menjamin kualitas produksi. Dengan didukung oleh jaringan distribusi yang tersebar dan diperkuat oleh delapan unit pengantongan semen yang melengkapi sarana distribusi penjualan, telah menjadikan perseroan sebagai pemasok terbesar di kawasan tersebut. Sarana pendukung operasi lainnya yang berkontribusi besar terhadap pencapaian laba perusahaan adalah utilitas
Pembangkit Listrik Tenaga Uap (PLTU) dengan kapasitas 2x25 MW yang berlokasi dekat dengan pabrik. Melihat akan kondisi lingkungan serta proses kerja yang sangat berisiko tinggi terhadap tingginya kecelakaan, maka PT. Semen Tonasa harus dapat memenuhi tanggung jawabnya dalam memberikan perlindungan dan kesejahteraan bagi para karyawannya dengan tetap menerapkan kedisiplinan dalam bekerja dan menaati aturan keselamatan dan kesehatan kerja.

Di perusahaan PT. Semen Tonasa pernah mengalami kecelakaan kerja akibat karyawan yang lalai terhadap peraturan dan tidak sedikit karyawan atau pekerja mengalami gangguan kesehatan akibat kurang disiplin dalam bekerja. Kedisiplinan karyawan di PT. Semen Tonasa menghambat tujuan perusahaan seperti halnya karyawan datang tidak tepat waktu, melawan atasan saat diberi nasehat, serta disiplin karyawan yang kurang adalah minum disaat jam kerja. Karyawan di PT. Semen Tonasa juga kurang memperhatikan kesehatan, karena sering melanggar peraturan dengan tidak menggunakan alat pelindung diri dengan baik dan benar seperti tidak memakai masker, dan sepatu septi. Kesehatan yang tidak baik akan mengurangi semangat kerja karyawan di perusahaan sehingga produktivitas menurun. Karyawan yang sakit atau karyawan yang menderita penyakit maupun yang sehat sudah diberikan tanggungan medical check up berkala stiap tanggal kelahiran para karyawan untuk 1 keluarga namun ada juga karyawan yang tidak melakukan medical check up, sehingga sanksinya tanggungan kesehatan tersebut dicabut atau tidak diberikan kepada yang bersangkutan dan diberikan kepada karyawan yang lain. Kedisiplinan dan kesehatan kerja merupakan salah satu faktor penting yang dapat mempengaruhi produktivitas kerja karyawan di pabrik PT. Semen Tonasa.

Perusahaan PT. Semen Tonasa Gerokgak Jalan Pelabuhan Celukan Bawang Bali menetapkan standar produksi 22.100 ton untuk bulan Januari dan Februari 2017, 24.700 ton untuk bulan Maret 2017, 23.500 ton untuk bulan April 2017, 23.200 ton untuk bulan Mei 2017, 
18.600 ton untuk bulan Juni 2017, dan 20.600 ton untuk bulan Juli 2017. Berdasarkan penelitian awal yang dilakukan, peneliti menemukan suatu permasalahan, yaitu tidak tercapainya target produksi yang ditetapkan oleh perusahaan pada bulan Januari sampai Juli tahun 2017 yang dalam rentan waktu tersebut karyawan hanya mampu memproduksi rata-rata 104.790 ton atau $68 \%$ selama bulan Januari sampai Juli tahun 2017. Data rekap produksi menunjukkan pada bulan Januari tahun 2017 karyawan hanya mampu memproduksi sebanyak 15.880 ton atau $72 \%$. Pada bulan Februari tahun 2017 karyawan hanya mampu memproduksi sebanyak 16.914 ton atau $77 \%$. Pada bulan Maret tahun 2017 karyawan hanya mampu memproduksi sebanyak 15,164 ton atau $61 \%$. Kemudian penurunan produksi yang cukup banyak terjadi pada bulan April tahun 2017 karyawan hanya mampu memproduksi 10.347 ton atau $44 \%$ dari target yang ditentukan. Pada bulan Mei tahun 2017 produksi karyawan hanya mampu memproduksi 16.209 ton atau $70 \%$. Pada bulan Juni tahun 2017 karyawan hanya mampu memproduksi sebanyak 13.157 ton atau $71 \%$. Selanjutnya, pada bulan Juli tahun 2017 karyawan hanya mampu memproduksi sebanyak 17.119 ton atau $83 \%$. Adapun tujuan penelitian ini adalah untuk mengetahui ada tidaknya pengaruh Kedisiplinan dan Kesehatan Kerja terhadap Produktivitas Kerja Karyawan pada PT. Semen Tonasa Gerokgak jalan Pelabuhan Celukan Bawang Bali.

\section{METODE}

Penelitian ini merupakan jenis penelitian kausal dengan pendekatan kuantitatif. Penelitian ini dilakukan untuk memperoleh informasi tentang pengaruh Kedisiplinan dan Kesehatan Kerja terhadap produktivitas kerja karyawan pada PT. Semen Tonasa Gerokgak jalan Pelabuhan Celukan Bawang Bali.

Metode pengumpulan data yang dilakukan adalah metode survei dengan menggunakan kuesioner. Variabel bebas dalam penelitian ini adalah kedisiplinan kerja (X1), kesehatan kerja (X2), dan produktivitas kerja karyawan $(\mathrm{Y})$ sebagai variabel terikat. Dengan pendekatan ini hasil penelitian diharapkan dapat menjelaskan mengenai pengaruh Kedisiplinan dan Kesehatan Kerja secara simultan dan parsial terhadap Produktivitas Kerja.

Variabel penelitian adalah objek penelitian, atau apa yang menjadi titik perhatian suatu penelitian (Arikunto, 2006), sedangkan Sugiyono (2007) mendefinisikan variabel sebagai segala sesuatu yang berbentuk apa saja yang ditetapkan oleh peneliti untuk dipelajari sehingga diperoleh informasi tentang hal tersebut, kemudian ditarik kesimpulannya. Jadi variabel penelitian adalah faktor-faktor yang berperan dalam peristiwa atau gejala yang akan diteliti. Dalam penelitian ini digunakan dua jenis variabel, yaitu variabel dependen (terikat) dan variabel independen (bebas). Variabel dependen dalam penelitian ini adalah produktivitas kerja dan variabel independennya adalah kedisiplinan kerja dan kesehatan kerja.

Jenis data dalam penelitian ini adalah data kuantitatif. Data kuantitatif, yaitu data yang berupa angka-angka. Data kuantitatif dalam penelitian ini berupa kedisiplinan kerja, kesehatan kerja dan produktivitas kerja. Sumber data dalam penelitian ini adalah data primer dan data sekunder. Data primer merupakan data yang di dapat langsung dari tempat penelitian yaitu data kedisiplinan, kesehatan dan produktivitas kerja. Data sekunder merupakan data yang diperoleh tidak secara langsung dari responden tetapi dari pihak ketiga. Subjek dalam penelitian ini adalah seluruh karyawan PT. Semen Tonasa. Objek dalam penelitian ini adalah kedisiplinan, kesehatan kerja dan produktivitas kerja karyawan. Sampel dalam penelitian ini adalah seluruh karyawan di PT. Semen Tonasa sebanyak 66 orang. Metode pengumpulan data merupakan teknik atau cara untuk mengumpulkan data. Teknik pengumpulan data yang digunakan dalam penelitian ini adalah kuesioner. Kuesioner dilakukan dengan memberikan seperangkat pertanyaan kepada responden (pimpinan dan karyawan) untuk dimintai keterangan mengenai variabel yang diteliti, yaitu kedisiplinan dan kesehatan kerja terhadap produktivitas kerja karyawan. Pengujian 
Instrumen dilakukan sebelum kuesioner disebarkan kepada responden, kuesioner akan diuji terlebih dahulu. Pengujian yang dipergunakan adalah Uji Validitas dan Uji Reliabilitas. Pengolahan data dalam penelitian ini dilakukan dengan program Statistic Product and Service Solution (SPSS) for windows.

Teknik analisis data yang digunakan dalam penelitian ini adalah menggunakan uji statistik yaitu uji $t$ (pengujian secara parsial), uji $f$ (pengujian secara simultan), regresi linier berganda dan uji asumsi klasik adalah salah satu metode pengujian hipotesis. Pengujian hipotesis dalam penelitian ini adalah yang pertama apabila $\mathrm{f}$-test > f-tabel, maka Ho ditolak dan $\mathrm{Ha}$ diterima berarti ada pengaruh yang positif atau signifikan secara simultan, yang kedua apabila f-test < f-tabel, maka Ho diterima dan $\mathrm{Ha}$ ditolak berarti tidak ada pengaruh yang positif atau signifikan secara simultan, yang ketiga apabila t-test > t-tabel, maka Ho ditolak dan $\mathrm{Ha}$ diterima, dan yang ke empat apabila t-test < t-tabel, maka Ho diterima dan Ha ditolak.

\section{HASIL DAN PEMBAHASAN Hasil}

Berdasarkan hasil penelitian yang dilakukan di PT.Semen Tonasa Gerokgak, maka untuk mengetahui pengaruh parsial kedisiplinan kerja terhadap produktivitas kerja diperoleh data kedisiplinan kerja terhadap produktivitas kerja pada PT. Semen Tonasa Gerokgak jalan Pelabuhan Celukan bawang, Bali. Data yang didapat dianalisis menggunakan teknik analisis data berupa analisis regresi linier berganda dengan bantuan program komputer SPSS 16.0 for windows. Maka hasil analisis yang menunjukkan besarnya pengaruh kedisiplinan kerja terhadap produktivitas kerja dapat dilihat pada tabel 1.

Tabel 1. Hasil perhitungan uji t kedisiplinan kerja terhadap produktivitas kerja Coefficients $^{\mathrm{a}}$

\begin{tabular}{|c|c|c|c|c|}
\hline \multirow[b]{2}{*}{ Model } & Unstandardized Coefficients & \multicolumn{2}{|l|}{$\begin{array}{l}\text { Standardized } \\
\text { Coefficients }\end{array}$} & \multirow[b]{2}{*}{ Sig. } \\
\hline & Std. Error & Beta & $\mathrm{T}$ & \\
\hline 1 (Constant) & 1.498 & & 4.563 & .000 \\
\hline Kedisiplinan kerja & .128 & .419 & 4.939 & .000 \\
\hline Kesehatan kerja & .155 & .528 & 6.226 & .000 \\
\hline $\begin{array}{l}\text { Berdasarkan tabel di atas, hal ir } \\
\text { dapat dilihat dari } \mathrm{t} \text {-test }=4,939 \text { diperoleh } \\
\text { tabel }=1,668(\mathrm{n}-\mathrm{k}) . \text { Karena nilai } \mathrm{t} \text {-test } \\
4,939>\mathrm{t} \text {-tabel }=1,668 \text {, maka koefisier } \\
\text { signifikan. Dari hasil penelitian ini dapa } \\
\text { disimpulkan bahwa } \mathrm{H}_{0} \text { ditolak dan } \mathrm{H}_{\mathrm{a}}\end{array}$ & $\begin{array}{l}\text { diter } \\
\text { berp } \\
\text { bes } \\
\text { terh } \\
\text { pad }\end{array}$ & $\begin{array}{l}\text { ima yang berarti } \\
\text { engaruh terhadap pr } \\
\text { Hasil analisis y } \\
\text { arnya pengaruh } \\
\text { adap produktivitas } \\
\text { a tabel } 2 \text {. }\end{array}$ & $\begin{array}{l}\text { kedisip } \\
\text { rodukti } \\
\text { yang } \\
\text { keseh } \\
\text { kerja }\end{array}$ & $\begin{array}{l}\text { an kerja } \\
\text { s kerja. } \\
\text { unjukkan } \\
n \text { kerja } \\
\text { at dilihat }\end{array}$ \\
\hline
\end{tabular}

Tabel 2. Hasil perhitungan uji t kesehatan kerja terhadap produktivitas kerja Coefficients $^{\mathrm{a}}$

\begin{tabular}{|c|c|c|c|c|c|}
\hline \multirow[b]{2}{*}{ Model } & \multicolumn{2}{|c|}{ Unstandardized Coefficients } & $\begin{array}{c}\text { Standardized } \\
\text { Coefficients }\end{array}$ & \multirow[b]{2}{*}{$\mathrm{T}$} & \multirow[b]{2}{*}{ Sig. } \\
\hline & $\mathrm{B}$ & Std. Error & Beta & & \\
\hline 1 (Constant) & 6.835 & 1.498 & & 4.563 & .000 \\
\hline Kedisiplinan kerja & .632 & .128 & .419 & 4.939 & .000 \\
\hline Kesehatan kerja & .967 & .155 & .528 & 6.226 & .000 \\
\hline
\end{tabular}


Berdasarkan tabel di atas, hal ini dapat dilihat dari t-test $=6,226$ diperoleh $\mathrm{t}$ tabel $=1,668(\mathrm{n}-\mathrm{k})$. Karena nilai $\mathrm{t}$-test $=$ $6,226>\mathrm{t}$-tabel $=1,668$, maka koefisien signifikan. Dari hasil penelitian ini dapat disimpulkan bahwa $\mathrm{H}_{0}$ ditolak dan $\mathrm{H}_{\mathrm{a}}$ diterima yang berarti kesehatan kerja berpengaruh terhadap produktivitas kerja.
Untuk mengetahui ada tidaknya pengaruh kedisiplinan kerja dan kesehatan kerja secara simultan terhadap produktivitas kerja digunakan analisis f-test. Hasil analisis pengaruh simultan kedisiplinan kerja dan kesehatan kerja terhadap produktivitas kerja dapat dilihat pada tabel

Tabel 3.

Hasil perhitungan uji f kedisiplinan kerja dan kesehatan kerja terhadap produktivitas kerja ANOVA $^{\text {b }}$

\begin{tabular}{crrrrr}
\hline Model & Sum of Squares & Df & Mean Square & F & Sig. \\
\hline 1Regression & 1425.010 & 2 & 712.505 & 96.737 & $.000^{\mathrm{a}}$ \\
Residual & 464.021 & 63 & 7.365 & & \\
Total & 1889.030 & 65 & & & \\
\hline
\end{tabular}

Hasil analisis tabel 3 diatas menunjukkan nilai $\mathrm{f}$-test $=96,737>\mathrm{f}$-tabel $=$ 3,15 atau $p$-value $0,000<\alpha=0,05$. Hal ini berarti Ha diterima dan Ho ditolak. Maka dengan demikian ada pengaruh secara simultan kedisiplinan kerja dan kesehatan kerja terhadap produktivitas kerja pada PT. Semen Tonasa, Gerokgak.
Untuk mengetahui besarnya pengaruh kedisiplinan kerja dan kesehatan kerja terhadap produktivitas kerja karyawan di perusahaan PT. Semen Tonasa, Gerokgak jalan Pelabuhan Celukan Bawang, Bali dapat digunakan analisis koefisien determinasi $\left(R^{2}\right)$. Besarnya koefisien determinasi $\left(R^{2}\right)$ dilihat pada tabel 4 .

Tabel 4. Hasil perhitungan Koefisien Determinasi $\left(R^{2}\right)$ dalam Model Summary Model Summary ${ }^{b}$

\begin{tabular}{crrrr} 
& \multicolumn{4}{c}{ Adjusted $\mathrm{R}$} \\
Model & $\mathrm{R}$ & $\mathrm{R}$ Square & Square & Std. Error of the Estimate \\
\cline { 2 - 5 } 1 & $.869^{\mathrm{a}}$ & .754 & .747 & 2.71393 \\
\hline
\end{tabular}

Berdasarkan hasil analisis pada tabel 4 dengan menggunakan program SPSS 16.0 for windows nilai dari output SPSS model Summary menunjukkan besarnya nilai Adjusted $\mathrm{R}^{2}$ menunjukkan bahwa besar pengaruh variabel kedisiplinan kerja dan kesehatan kerja terhadap produktivitas kerja sebesar 0,747 sehingga sumbangan pengaruh dari variabel kedisiplinan kerja (X1) dan kesehatan kerja (X2) terhadap produktivitas kerja $(\mathrm{Y})$ sebesar $74,7 \%$. Hal ini berarti kedisiplinan kerja dan kesehatan kerja di PT. Semen Tonasa, Gerokgak sebesar $74,7 \%$ dipengaruhi oleh variabel produktivitas kerja karyawan, sedangkan sisanya sebesar $25,3 \%$ dipengaruhi oleh faktor lain yang tidak termasuk dalam penelitian ini.

Uji asumsi klasik adalah persyaratan analisis yang harus dipenuhi pada analisis regresi linier berganda. Persamaan regresi memiliki keunggulan sebagai penaksir yang paling baik maka persamaan regresi tersebut harus bebas. Uji yang dilakukan adalah Uji multikolonieritas bertujuan untuk mendeteksi adanya multikolonieritas atau tidak dengan melihat nilai VIF (Variance Influence Factor) dan Tolerance. Apabila nilai VIF $<10$ dan tolerance $>0,10$ maka model regresi yang digunakan tidak terjadi multikolonieritas. Hasil output SPSS uji multikolonieritas dapat dilihat pada tabel 5 . 
Tabel 5. Hasil Uji Multikolonieritas

Coefficients $^{a}$

\begin{tabular}{|c|c|c|c|c|c|}
\hline \multirow[b]{2}{*}{ Model } & \multicolumn{2}{|c|}{$\begin{array}{l}\text { Unstandardized } \\
\text { Coefficients }\end{array}$} & \multirow{2}{*}{$\begin{array}{c}\text { Standardize } \\
d \\
\text { Coefficients } \\
\text { Beta }\end{array}$} & \multirow{2}{*}{\multicolumn{2}{|c|}{ Sig. }} \\
\hline & B & Std. Error & & & \\
\hline 1 (Constant) & 6.835 & 1.498 & & .000 & \\
\hline Kedisiplinan kerja & .632 & .128 & .419 .542 & .000 & 1.846 \\
\hline Kesehatan kerja & .967 & .155 & $.528 \quad .542$ & .542 & 1.846 \\
\hline \multicolumn{3}{|c|}{$\begin{array}{l}\text { Dari tabel di atas menunjukkan bahwa } \\
\text { nilai tolerance kedisiplinan kerja (X1) } 0,542 \\
>0,1 \text { dan nilai VIF } 1,846<10 \text {. Nilai } \\
\text { tolerance kesehatan kerja (X2) } 0,542>0,1 \\
\text { dan nilai VIF. } 1,846<10 \text {. Nilai tolerance } \\
\text { masing-masing variabel lebih besar dari } 0,1 \\
\text { dan nilai VIF lebih kecil dari } 10 \text {. Maka dapat } \\
\text { disimpulkan bahwa tidak terjadi } \\
\text { multikolonieritas antar variabel independen } \\
\text { dalam model regresi. } \\
\text { Uji heteroskedastisitas untuk menguji } \\
\text { apakah ditemukan variabel gangguan } \\
\text { variabel residual yang tidak mempunyai }\end{array}$} & \multicolumn{3}{|c|}{$\begin{array}{l}\text { varian yang sama untuk semua observasi. } \\
\text { Jika terjadi suatu keadaan dimana variabel } \\
\text { gangguan tidak mempunyai varian yang } \\
\text { sama untuk semua observasi maka dapat } \\
\text { dikatakan dalam model regresi tersebut } \\
\text { gejala heteroskedastisitas. Ada tidak nya } \\
\text { heteroskedastisitas dapat dilihat pada } \\
\text { koefisien beta pada uji heteroskedastisitas. } \\
\text { Uji heteroskedastisitas terjadi apabila nilai } \\
\text { profitabilitas lebih besar dari nilai Sig }>\text { a } \\
0,05 \text { Hasil SPSS dari uji } \\
\text { heteroskedastisitas dapat dilihat pada tabel } \\
6 \text {. }\end{array}$} \\
\hline
\end{tabular}

Tabel 6. Hasil Uji Heteroskedastisitas

Coefficients $^{\mathrm{a}}$

\begin{tabular}{|c|c|c|c|c|c|}
\hline \multirow[b]{2}{*}{ Model } & \multicolumn{2}{|c|}{$\begin{array}{l}\text { Unstandardized } \\
\text { Coefficients }\end{array}$} & $\begin{array}{l}\text { Standardized } \\
\text { Coefficients }\end{array}$ & \multirow[b]{2}{*}{$\mathrm{t}$} & \multirow[b]{2}{*}{ Sig. } \\
\hline & $\mathrm{B}$ & Std. Error & Beta & & \\
\hline (Constant) & 6.187 & 4.883 & & 1.267 & .210 \\
\hline Kedisiplinan kerja & -.154 & .417 & -.063 & -.369 & .713 \\
\hline Kesehatan kerja & .241 & .506 & .081 & .477 & .635 \\
\hline
\end{tabular}

Data tabel di atas menunjukkan bahwa nilai signifikan variabel bebas 0,210 $>0,05$. Maka disimpulkan bahwa variabel kedisiplinan kerja dan kesehatan kerja tidak terjadi heteroskedastisitas pada model regresi karena nilai signifikan $>0,05$.

Uji normalitas bertujuan untuk menguji apakah dalam model regresi variabel pengganggu atau residual mempunyai distribusi normal atau tidak, seperti yang diketahui bahwa uji $t$ dan uji $f$ mengasumsikan nilai residual mengikuti distribusi normal. Data-data yang pada umumnya mengikuti asumsi berdistribusi normal. Tetapi ada pula data tidak mengikuti asumsi normalitas. Untuk mengetahui data penelitian ini berdistribusi normal atau tidak, maka harus dilakukan uji normalitas terhadap data yang diperoleh dari tempat penelitian. Dengan demikian, uji normalitas dalam penelitian ini untuk mengetahui dan menguji variabel independen terhadap variabel dependen. Jika asumsi ini dilanggar maka uji statisitik menjadi tidak valid untuk jumlah sampel kecil. Uji normalitas diharapkan berdistribusi normal. Penelitian untuk uji normalitas menggunakan grafik probability p-plot dan one-sampel kolmogorov-smirnov, bila $p$ value $>0,05$ maka data dalam penelitian ini berdistribusi normal. Hasil output SPSS uji normalitas dapat dilihat pada tabel 7 . 
Tabel 7. Hasil Uji Normalitas

One-Sample Kolmogorov-Smirnov Test

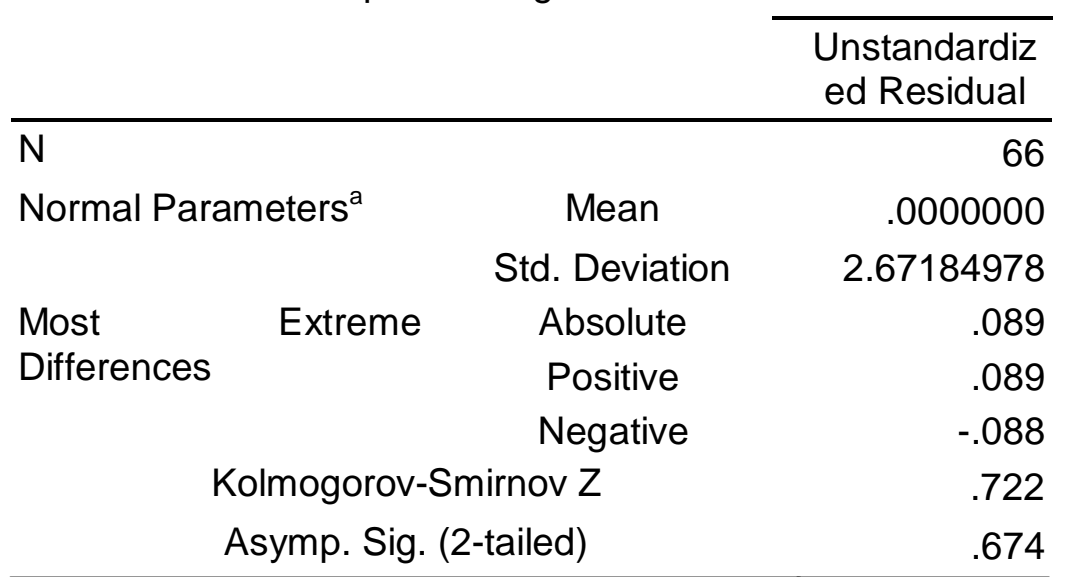

Dari tabe di atas dengan nilai Asymp.

Sig sebesar 0,674 >0,05 maka dapat disimpulkan bahwa data-data penelitian terdistribusi normal.

Berdasarkan pengolahan data yang digunakan untuk mengetahui persamaan garis regresi, pengaruh kedisiplinan kerja dan kesehatan kerja terhadap produktivitas kerja karyawan pada PT. Semen Tonasa, Gerokgak digunakan analisis koefisien beta. Besarnya koefisien beta dapat dilihat pada tabel

Tabel 8. Hasil perhitungan Koefisien Beta Coefficients $^{\mathrm{a}}$

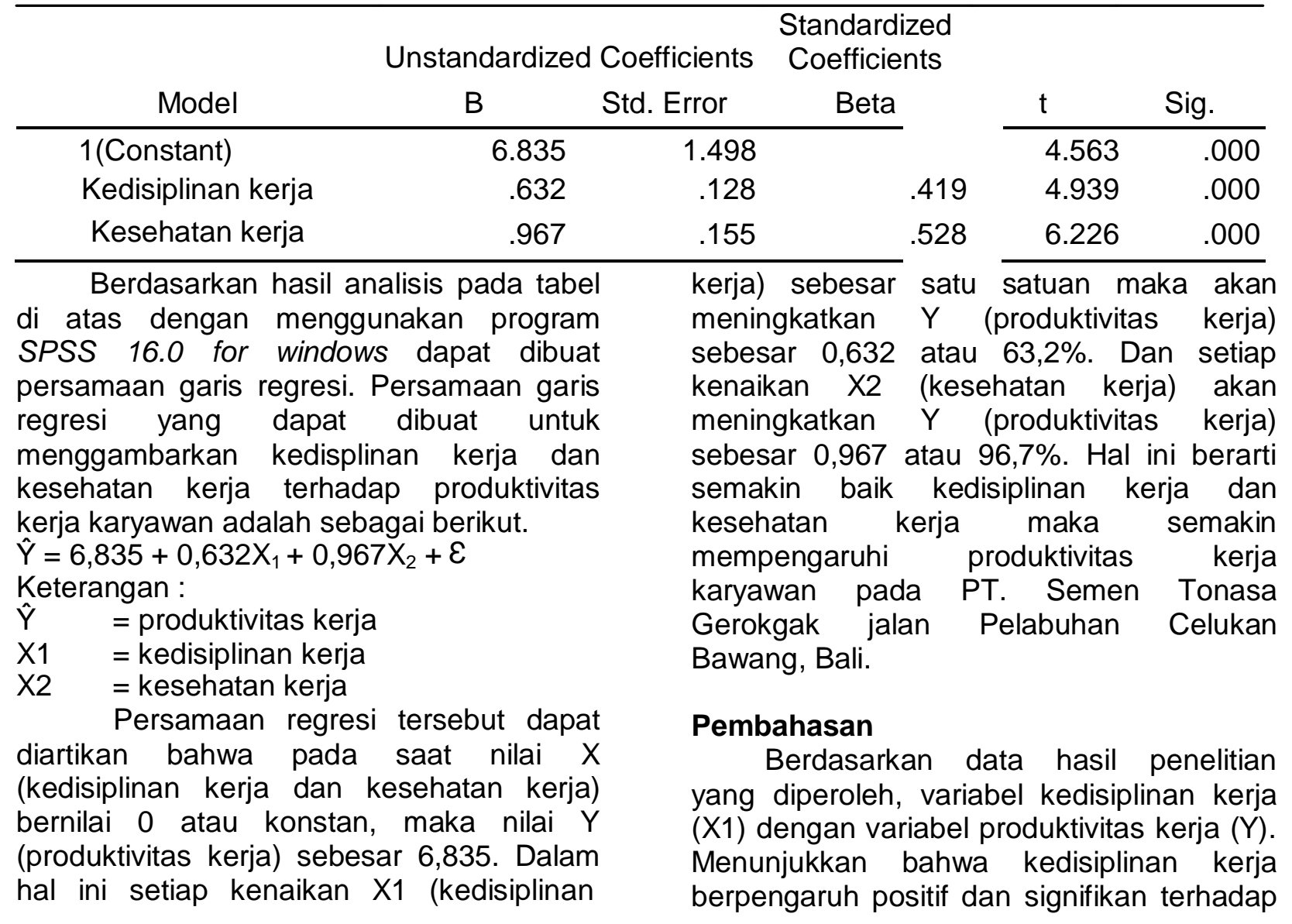


produktivitas kerja pada PT. Semen Tonasa Gerokgak. Hasil analisis pada tabel 1 nilai ttest $=4,939>\mathrm{t}$-tabel $=1,668$. Hasil penelitian ini menunjukkan bahwa kedisiplinan memberikan pengaruh yang sangat besar terhadap produktivitas kerja pada PT. Semen Tonasa Gerokgak. Hal ini sejalan dengan pendapat Hasibuan (2012:193) "kedisiplinan merupakan fungsi operatif manajemen sumber daya manusia yang terpenting karena semakin baik disiplin karyawan, semakin tinggi prestasi kerja yang dapat dicapainya. Produktivitas akan tercipta jika karyawan dapat meningkatkan produktivitas melalui disiplin dalam bekerja". Hal ini memperlihatkan bahwa kedisiplinan kerja memiliki peran yang penting dalam upaya meningkatkan produktivitas kerja di PT. Semen Tonasa.

Berdasarkan hasil penelitian antara variabel kesehatan kerja $\left(\mathrm{X}_{2}\right)$ dengan variabel produktivitas kerja (Y). Menunjukkan bahwa kesehatan kerja berpengaruh positif dan signifikan terhadap produktivitas kerja pada PT. Semen Tonasa Gerokgak. Hasil analisis pada tabel 2 nilai ttest $=6,226>\mathrm{t}$-tabel $=1,668$. Hasil penelitian ini menunjukkan bahwa kesehatan kerja sangat berpengaruh terhadap produktivitas kerja pada PT. Semen Tonasa Gerokgak. Hal ini sejalan dengan pendapat dari Notoatmodjo (2002) menyatakan bahwa kesehatan kerja adalah merupakan aplikasi kesehatan masyarakat di dalam suatu tempat kerja (perusahaan, pabrik, kantor, dan sebagainya) dan yang menjadi pasien dari kesehatan kerja ialah masyarakat pekerja dan masyarakat sekitar perusahan. Semakin tinggi kesehatan karyawan yang dirasakan akan semakin tinggi pula tingkat produktivitas yang dihasilkan, sehingga berdampak positif bagi karyawan dan perusahaan. Hal ini memperlihatkan bahwa kesehatan kerja memiliki peran yang penting dalam upaya meningkatkan produktivitas kerja di PT. Semen Tonasa, Gerokgak. Selain itu temuan dari penelitian yang dilakukan oleh Arlin Riantiwi menunjukkan hasil bahwa terdapat hubungan yang kuat antara pelaksanaan program K3 dengan produktivitas kerja karyawan.

Berdasarkan hasil penelitian antara variabel kedisiplinan kerja $\left(X_{1}\right)$ dan kesehatan kerja $\left(\mathrm{X}_{2}\right)$ terhadap produktivitas kerja $(\mathrm{Y})$ menunjukkan bahwa berpengaruh positif dan signifikan. Hal ini memperlihatkan bahwa kedisiplinan kerja dan kesehatan kerja memiliki peran yang penting dalam upaya meningkatkan produktivitas kerja di PT. Semen Tonasa, Grokgak. Hasil analisis pada tabel 3 menunjukkan nilai f-test $=96,737>\mathrm{f}$-tabel $=$ 3,15 atau p-value $0,000<\alpha=0,05$. Persamaan regresi yang dibuat untuk menggambarkan pengaruh kedisiplinan kerja dan kesehatan kerja terhadap produktivitas kerja karyawan adalah dengan menggunakan uji multikolonieritas, heteroskedastisitas dan normalitas memperoleh persamaan regresi sebagai berikut: $\hat{Y}=6,835+0,632 X_{1}+0,967 X_{2}+\varepsilon$.

Hasil ini membuktikan relevasi pendapat dari Sunyoto (2012), bahwa terdapat empat belas faktor yang mempengaruhi produktivitas kerja karyawan diantaranya pendidikan, keterampilan, disiplin, sikap mental dan etika kerja, motivasi, gizi dan kesehatan, tingkat penghasilan, jaminan sosial, lingkungan dan iklim kerja, hubungan industrial Pancasila, teknologi, sarana produksi, manajemen, dan kesempatan berprestasi.

Hasil analisis membuktikan bahwa semua koefisien signifikan. Nilai koefisien $X_{1}$ terhadap $Y$ sebesar 4,939 dan $X_{2}$ terhadap $Y$ sebesar 6,226. Sedangkan koefisien determinan atau kontribusi $X_{1}$ dan $\mathrm{X}_{2}$, terhadap $\mathrm{Y}$ adalah $\mathrm{R}^{2} \mathrm{yx}_{1} \mathrm{x}_{2}=0,747$ yang berarti bahwa $74,7 \%$ variasi produktivitas kerja dapat dijelaskan oleh variasi kedisplinan kerja dan kesehatan kerja. Besar koefisien residu $P^{2} y \varepsilon=\sqrt{ }(1-$ $0,747)=0,253$ merupakan pengaruh variabel lain diluar variabel kedisiplinan kerja dan kesehatan kerja.

\section{SIMPULAN DAN SARAN}

Berdasarkan hasil pembahasan yang telah diuraikan maka dapat disimpulkan bahwa kedisiplinan kerja dan kesehatan kerja berpengaruh secara parsial dan simultan terhadap produktivitas kerja pada PT. Semen Tonasa Gerokgak jalan Pelabuhan Celukan Bawang, Bali ditunjukkan dengan nilai $\mathrm{t}$-test $=4,939$ untuk kedisiplinan kerja, nilai t-test $=6,226$ 
untuk kesehatan kerja dan secara simultan dengan nilai f-test $=96,737>\mathrm{f}$-tabel $=3,15$ atau $p$-value $0,000<\alpha=0,05$.

Adapun saran yang dapat disampaikan berdasarkan hasil penelitian yang telah dilakukan yaitu, yang pertama bagi pihak perusahaan dalam upaya meningkatkan produktivitas kerja, karyawan hendaknya harus mematuhi peraturan diperusahaan dengan disiplin dalam bekerja dan menjaga kesehatan agar dapat bekerja dengan baik tanpa ada gangguan fisik maupun mental. Yang kedua bagi pimpinan harus lebih tegas dan memperhatikan bawahan agar tidak terjadi hal yang tidak diinginkan. Yang ketiga bagi mahasiswa lain yang meneliti pengaruh kedisiplinan kerja dan kesehatan kerja terhadap produktivitas kerja karyawan agar mengembangkan penelitian ini lebih lanjut dan mempertimbangkan variabel lain yang belum diuji dipenelitian ini.

\section{DAFTAR PUSTAKA}

Arikunto, S. 2006. Metodelogi Penelitian. Yogyakarta: Bima Aksara.

Buhler. 2007. Manajemen Tenaga Kerja. Bandung: Sinar Baru.

Ervianto, I. 2004. Teori Aplikasi Manajemen Proyek Konstruksi. Yogyakarta: Salemba Empat.

Gomes. 2000. Manajemen Sumber Daya Manusia. Yogyakarta: Andi.

Hasibuan, M.S.P. 2014. Manajemen: Dasar, Pengertian, dan Masalah. Jakarta: PT. Bumi Aksara.

-------. 2012. Manajemen Sumber Daya Manusia. Jakarta: PT. Bumi Aksara.

Mathis \& Jacson. 2002. Sumber Daya Manusia. Jakarta: Salemba Empat.

Mangkunegara, A.P. 2000. Manajemen Sumber Daya Manusia Perusahaan. Bandung: PT. Remaja Rosdakarya

Notoatmodjo, S. 2002. Metodologi Penelitian Kesehatan. Jakarta: Rineka Cipta.

Sugiyono, 2007. Metode Penelitian Bisnis (Pendekatan Kuantitatif Kualitatif dan $R$ \& D). Bandung: Alfabeta.
Sutrisno, E. 2009. Manajemen Sumber Daya Manusia. Jakarta: Kencana.

Singodimedjo, M. 2000. Manajemen Sumber Daya Manusia. Surabaya: SMMAS.

Sunyoto, D. 2012. Manajemen Sumber Daya Manusia Teori, Kuesioner, dan Analisis Data. Yogyakarta: CAPS 